\author{
Alieksieienko Iryna, \\ Doctor of Political Sciences, Professor, \\ Head of the Department of International \\ Relations and Tourism of the \\ Dnipropetrovsk State University of \\ Internal Affairs, Dnipro, Ukraine \\ ORCID ID 0000-0002-6873-003
}

\title{
RECONCEPTUALIZATION OF MIGRATION PROCESSES OF THE GLOBALIZATION AGE: POLITICAL AND LEGAL ASPECT
}

Paper studies theoretical issues of reconceptualization of modern migration processes, analyzes its features. Emphasis is placed on new forms and types of migration processes, taking into account the challenges and threats for globalization. The specifics of the transformation tendencies of the development of these processes are actualizeded, as well as the development of practical recommendations for the improvement of the migration policy in both international political space and Ukraine.

It was stated that regulation of migration processes at the macrolevel should become a significant component of the socio-economic policy of the states of the international apolitical space.

The task of managing migration, especially of its external forms, is not to erect barriers by introducing a system of restrictive measures that will prevent migrants from reaching developed countries, but rather through the respect to human rights and humane principles to manage the migration flows of the population, in particular, permanent migrants, labor migrants, intellectual migrants, women-migrants, taking into account the interests of donors and recipients. In other words, regulation of migration processes is not about restriction of freedom of choice, but about support in solving of this problem in each case within the framework that is appropriate for society and desirable for the individual. 
Migration policy measures (especially at the regional level) are based on the available scientific, technical, organizational and financial means to achieve the ordering of the migration space and to take under control the migration processes.

At present, the issue of formation of a full-fledged complex of criminal-legal measures to counteract illegal migration is particularly relevant; the severity of economic sanctions against employers who employ illegal workers; formation of a single information space and labor market of the CIS countries; organization of an interaction of the Ministry of Internal Affairs of Ukraine with interested agencies of other countries on joint detection and termination of activity of criminal groups engaged in the organization of channels of illegal immigration.

Keywords: migration, transboundary migration, legitimate structures of migration, illegitimate actors of migration, globalization, sexual slavery, human traffic, woman migration.

\section{REFERENCES}

1. Bakhchevanova N.V. (2011) Mizhnarodna mihratsiia robochoi syly v umovakh hlobalizatsii. "International Labor Migration in the Conditions of Globalization". Financial and Credit Activities: Problems of Theory and Practice". Kharkiv: Banking University. Vol. 2. No 11.9 p. [in Ukrainian].

2. Volosko Ya.O. (2015) Mizhnarodna trudova mihratsiia naselennia: prychyny vynyknennia ta naslidky dlia ekonomiky. "International Labor Migration of the Population: Causes and Consequences for the Economy". Lviv: Bulletin of the National University "Lviv Polytechnic". Law 824, P. 21-26. [in Ukrainian].

3. Dannett K. (2015) Vidtik mizkiv z Ukrainy mozhe prynesty yi nespodivani «bonusy». "A brain drain from Ukraine can bring it unexpected “Bonuses". VoxUkraine. URL: https://gazeta.ua/articles/dunnett/_vidtik-mizkiv-zukrayini-mozhe-prinesti-yij-nespodivani-bonusi/625184 (date of application: 22.10.2019) [in Ukrainian].

4. Dron Ye.V., Zankovska V.H. Trudova mihratsiia v Ukraini : tendentsii ta naslidky. "Labor Migration in Ukraine: Tendencies and Consequences". University of Bukovina. 7 p. URL: http://zbirnuk.bukuniver.edu.ua/issue_articles/38.pdf (date of application: 22.10.2019) [in Ukrainian]. 
5. Kulchytska K., Sushko I. (2017) Nevrehulovana i vymushena mihratsiia z Ukrainy do YES pered otrymanniam bezvizovoho rezhymu: mozhlyvi naslidky ta ochikuvannia. "Non-Regulated and Forced Migration from Ukraine to the EU before Visa-Free Travel: Possible Consequences and Expectations". Barrier-free Europe. 8 p. [in Ukrainian].

6. Malynovska O.A. (2011) Naslidky mizhnarodnoi mihratsii naselennia Ukrainy ta polityko-upravlinski diyi shchodo yikh vrehuliuvannia. "Consequences of International Migration of the Population of Ukraine and Political and Administrative Actions for their Settlement". Analytical Note. National Institute for Strategic Studies. URL: http: //www.niss.gov.ua/articles/562/ (date of application: 22.10.2019) [in Ukrainian].

7. Mihratsiini protsesy v Ukraini: suchasnyi stan i perspektyvy. "Migration Processes in Ukraine: Current State and Prospects": monograph / NAS of Ukraine; Institute of Demography and Social Research; O.V. Pozniak (Ed.). Uman: SPD Sochi, 2007. 276 p. [in Ukrainian].

8. Pelka K. (2013) Kharakterystyka kontseptsii mihratsiinoi polityky Ukrainy ta napriamy yii rozvytku. "Characterization of the Concept of Migration Policy of Ukraine and Directions of Its Development". IAUP Scientific Papers. Issue 2 (37). P. 66-71 [in Ukrainian].

9. Piatkovska, O.R. (2015) Mekhanizmy rehuliuvannia mizhnarodnoi trudovoi mihratsii: vyznachennia operatsiinoho poniattia. "Mechanisms of Regulation of International Labor Migration: Definition of Operational Concept". Global and National Problems of Economy". Mykolaiv: Mykolaiv National University named after V.O. Sukhomlinsky. Vol. 8. P.66-70 [in Ukrainian].

10. Statystychnyi shchorichnyk Ukrainy za 2014 rik / "Ukrstat Statistical Yearbook of Ukraine for 2014" / Ukrstat / ed. I.M. Zhuk; resp. for the issue O.A. Vyshnevska. Kyiv: State Statistics Service of Ukraine, 2015. 239 p. [in Ukrainian].

11. Kolesnikova J., Camille R., Kamasheva A., Yue Z. Current trends of realization of the intellectual capital and problems of intellectual migration. Procedia Economics and Finance, 2014. Vol. 14. P. 326-332 [in English]. 
12. Lee E. A Theory of Migration / Demography, 1966. No. 3(1). P. 47-57 [in English].

13. Number of internet users worldwide from 2005 to 2017 / Statista, 2017. URL: https://www.statista.com/statistics/273018/number-of-internet-usersworldwide/ (date of application: 22.10.2019) [in English].

14. World Investment Report 2013: Global Value Chains: Investment and Trade for Development // UNCTAD, 2013. 44 p. [in English]. 